\title{
АНАЛІЗ ФАКТОРІВ ПОРУШЕННЯ РЕПРОДУКТИВНОЇ ФУНКЦІї В ЖІНОК ІЗ БЕЗПЛІДДЯМ НА ФОНІ ЛЕЙОМІОМИ МАТКИ В ПРОГРАМАХ ДОПОМІЖНИХ РЕПРОДУКТИВНИХ ТЕХНОЛОГІЙ
}

Тернопільський національний медичний університет

\author{
імені І. Я. Горбачевського МОЗ України, м. Тернопіль, Україна
}

\begin{abstract}
Мета: вивчити фрактори порушення репродуктивної фрункції у безплідних жінок із лейоміомою матки шляхом аналізу гормонального та імунологічного гомеостазу та в подальшому оптимізації лікувально-профрілактичного комплексу.

Матеріали і методи. Рандомізоване проспективне клінічне дослідження проведено серед 175 (29,0 \%) жінок репродуктивного віку, в яких діагностовано лейоміому матки, які були поділені на такі групи: основна група 137 жінок із лейоміомою матки зі запропонованим лікуванням; група порівняння - 38 жінок з лейоміомою матки та загальноприйнятим лікуванням та 32 соматично здорових жінок з нормальною менструальною та репродуктивною фрункціями (контрольна група).

Результати. У результаті проведеного аналізу репродуктивної гормональної панелі в обстежених жінок основної групи на 2-3 дні менструального циклу виявлено зменшення концентрації естрадіолу при незміненому рівні прогестерону $(p>0,05)$ та достовірне зниження прогестерону в жінок основної групи й групи порівняння на 21-й день циклу. У жінок основної групи та групи порівняння спостерігали статистично вагоме зменшення рівня естрадіолу в крові $((60,27 \pm 0,004)$ та $(66,69 \pm 0,003)$ нмоль/л). Отримано зниження співвідношення лютеїнізуючого гормону до фролікулостимулювального у межах 1,18-1,2 при необхідному фрізіологічному балансі $(1,5-2,0)$, що свідчить про відхилення в гормонопродукувальній функції яєчників.

Висновки. Виявлені зміни специфічного та неспецифічного імунітету в жінок із безпліддям на фроні лейоміоми матки в програмах допоміжних репродуктивних технологій мають субкомпенсований характер за рахунок зниження потенційної здатності бактерицидної активності фрагоцитарних клітин, зниження коесріцієнта активності фрагоцитарних клітин на 52,4 \%, збільшення імунологічного коефіцієнта та відносної кількості О-лімфоцитів; зменшення на 48,2 \% відносної кількості Т-лімфоцитів, лейко-Т-клітинного індексу та імунорегуляторного індексу на фроні збільшення на 50,3 \% відносної кількості CD8+ цитолітичних лімфоцитів.
\end{abstract}

КЛЮЧОВІ СЛОВА: безпліддя; лейоміома матки; стероїдні гормони; уроджений неспецифічний імунітет; специфічний імунітет; допоміжні репродуктивні технології.

Встановлено, що безплідний шлюб діагностують у 10,0-20,0 \% подружніх пар $[1,3,6]$. Лейоміома матки (ЛМ) є одним з провідних чинників розвитку безпліддя як вторинного, так і первинного, її виявляють в 13,3-24,0\% [2, 4]. Збільшується частота виявлення ЛМ до 35,0-45,0 \% у жінок після 35 років, відповідно, відбувається порушення рівня у гіпоталамо-гіпофрізо-яєчниковій системі внаслідок змін рівнів фролікулостимулювального гормону (ФСГ), лютеїнізуючого гормону (ЛГ), пролактину, прогестерону та естрогенів; зниження рецепторного апарату матки до впливу стероїдних гормонів за рахунок змін у формуванні локальних автономних механізмів підтримки росту, які є основними пусковими механізмами росту ЛМ $[5,8]$. Проведений детальний аналіз літературних публікацій провідних фрахівців, які вивчали даний напрямок, свідчить, що частота відновлення репродуктивної функції становить 30,0-37,0 \% хворих після міомектомії за рахунок розміщення вузлів біля трубних кутів матки, деформації іï порожнини $[2,4,7]$. На сьогодні достовірно не вирішено питання оптимального методу лікування жінок з лейоміомою матки та нереалізованим репродуктивним потенціалом. Таким чином, оцінка методу оптимізації реалізації репродуктивної фрункції з цією патологією $€$ актуальним завданням гінекології та репродуктології.

Мета дослідження: вивчити фрактори порушення репродуктивної функції у безплідних жінок із лейоміомою матки шляхом аналізу гормонального та імунологічного гомеостазу та в подальшому оптимізації лікувально-профрілактичного комплексу.

Матеріали і методи. Рандомізоване клінічне дослідження проведено на базі Медичного центру «Клініка профресора Стефрана Хміля» впродовж 
2014-2020 рр. На І етапі проведено аналіз амбулаторних історій 603 жінок репродуктивного віку 3 операціями на органах малого таза, у подальшому в проспективний аналіз включено 175 (29,0 \%) жінок репродуктивного віку, в яких діагностовано лМ, які були поділені на такі групи: основна група - 37 жінок із ЛМ, яка надалі для оцінки проведеного лікування була поділена на 3 підгрупи: 1-ша - 55 жінок з лм після лапаро- та гістероскопії із запропонованим лікувальним комплексом (ЛК), 2-га - 45 жінок із ЛМ після гістероскопії та ЛК, 3-тя - 37 із Лм та запропонованим медикаментозним лікуванням без оперативного видалення ЛМ; група порівняння - 38 жінок 3 лм та загальноприйнятим лікуванням та 32 соматично здорових жінок з нормальною менструальною та репродуктивною функціями (контрольна група).

Усі пацієнтки підлягали детальному традиційному клініко-лабораторному обстеженню в гінекології відповідно до локальних протоколів, які затверджені в даній клініці, щодо ведення пацієнток з матковим фрактором безпліддя та наказу Міністерства охорони здоров'я України від 09.09.2013 р. № 787 «Про затвердження Порядку застосування допоміжних репродуктивних технологій в Україні». Гормональний статус пацієнток визначали за вмістом у крові пролактину (Прл), лютеїнізуючого гормону, фролікулостимулювального гормону, естрадіолу (Е2), тестостерону (Т), кортизолу (К), прогестерону (П), тиреотропного гормону (ТТГ), трийодотироніну (ТЗ) і тироксину (T4) за традиційними методиками. У даному дослідженні використано стандартні клініко-лабораторні обстеження згідно з нормативним документом (локальним наказом) надання амбулаторної та стаціонарної акушерсько-гінекологічної допомоги до та після операції міомектомії. Оцінено наслідки оперативного лікування лм і післяопераційного стану функцій жіночого організму, а саме менструальної, статевої та репродуктивної. Дослідження проведено відповідно до принципів Гельсінської декларації прав людини, Конвенції Ради Європи про права людини і біомедицину та відповідних законів України.
Статистичні методи дослідження виконано за допомогою ліцензійної програми Statistica (версія 10; Statsoft, США). Для обробки кількісних величин застосовували традиційні методи параметричної статистики (середня величина, помилка середньої величини). Достовірність відмінностей між груповими середніми значеннями вивчали за критерієм Стьюдента для рівня статистичної значущості ( $p<0,05, x=95$ \%).

Результати дослідження та їх обговорення. Відповідно до мети та завдань проведено вивчення стану гормонального гомеостазу, а саме вмісту базальних рівнів гонадотропних і статевих гормонів у сироватці крові на 2-3-й і прогестерону - на 21-й день менструального циклу в плазмі крові у жінок із безпліддям та ЛМ основної, порівняння та контрольної груп.

Отримані результати досліджень свідчать про те, що в обстежених жінок основної групи на 2-3 дні менструального циклу виявлено зменшення концентрації естрадіолу при незміненому рівні прогестерону ( $>0,05)$, але було зафіксовано достовірне зниження прогестерону в жінок основної групи й групи порівняння на 21-й день циклу, що вказує на наявність лютеїнізації фолікула. Аналіз отриманих даних показав, що рівень пролактину в усіх досліджуваних групах не відрізнявся. Значення лютеїнізуючого та фролікулостимулювального гормонів у жінок основної та групи порівняння були нижчими відносно показників контрольної групи (р>0,05). У жінок основної групи та групи порівняння спостерігали статистично вагоме зменшення рівня естрадіолу в крові $((60,27 \pm 0,004)$ та $(66,69 \pm 0,003)$ нмоль/л). Дані зміни зниження рівня естрогенів у крові пацієнток основної та групи порівняння до етапу контрольованої стимуляції яєчників зайвий раз вказує на відхилення в ендокринній функції, першочергово гормонопродукувальної функції яєчників, яка зумовлена аутоімунними процесами та впливом комплексів антиген - антитіло та біологічно активних амінів на фолікулярний апарат яєчника.

Результати, які ми отримали при дослідженні базового рівня гормонів, наведено в таблиці 1.

Таблиця 1. Концентрація гіпофізарних та яєчникових гормонів у крові жінок

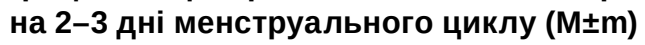

\begin{tabular}{|c|c|c|c|c|}
\hline Показник & $\begin{array}{c}\text { Основна група } \\
(n=137)\end{array}$ & $\begin{array}{c}\text { Група порівняння } \\
(\mathrm{n}=38)\end{array}$ & $\begin{array}{c}\text { Контрольна група } \\
(\mathrm{n}=32)\end{array}$ & $p$ \\
\hline ЛГ, мМО/мл & $6,05 \pm 1,28$ & $6,12 \pm 1,31$ & $9,82 \pm 1,70$ & $>0,05$ \\
\hline ФСГ, мМО/мЛ & $5,12 \pm 1,16$ & $5,07 \pm 1,16$ & $5,31 \pm 1,16$ & $<0,05$ \\
\hline ЛГ/ФСГ & 1,18 & 1,2 & 1,84 & \\
\hline E2, пг/мл & $60,52 \pm 0,004^{*}$ & $66,69 \pm 0,003^{*}$ & $198,69 \pm 0,005$ & $<0,01$ \\
\hline ПРЛ, нг/мЛ & $14,9 \pm 1,3$ & $15,1 \pm 1,2$ & $17,6 \pm 0,8$ & $<0,05$ \\
\hline П, нг/мл & $0,81 \pm 0,1$ & $0,78 \pm 0,2$ & $0,84 \pm 0,1$ & $>0,05$ \\
\hline П, нг/мл (21 день) & $1,32 \pm 0,34^{*}$ & $1,29 \pm 0,28^{\star}$ & $11,4 \pm 0,21$ & $>0,05$ \\
\hline $\mathrm{T}$, пг/мл & $1,49 \pm 2,4$ & $1,52 \pm 2,4$ & $1,62 \pm 2,4$ & $>0,05$ \\
\hline
\end{tabular}

Примітка. * - різниця вірогідна порівняно 3 контрольною групою. 
Співвідношення ЛГ до ФСГ в обстежених групах було в межах 1,18-1,2. Цей коефріцієнт дещо нижчий, що можна пояснити порушенням з боку центральної регуляції репродуктивної системи. Для повноцінного розвитку фролікула необхідний фрізіологічний баланс між ФСГ та ЛГ у межах $(1,5-2,0)$. Зафріксовано збільшення рівня естрогенів у крові обстежених пацієнток та співвідношення ЛГ/ФСГ склало відповідно: 1,24 та 1,31 на 14-й день менструального циклу. Проаналізувавши отримані по- казники гонадотропних гормонів та відсутність суттєвих змін, можемо стверджувати, що задіяні компенсаторні реакції організму при цьому забезпечують овуляцію в 2/3 обстежених пацієнток, у той час як репродуктивна фрункція виявляється значно порушеною та проявляється безпліддям.

Проаналізовано показники відносної та абсолютної кількості основних імунокомпетентних клітин у периферійній крові в жінок із безпліддям на фоні лейоміоми матки (табл. 2).

\section{Таблиця 2. Абсолютна та відносна кількість основних імунокомпетентних клітин} у обстежених жінок $(\mathrm{M} \pm \mathrm{m})$

\begin{tabular}{|l|c|c|c|c|}
\hline \multirow{2}{*}{\multicolumn{1}{|c|}{ Показник }} & \multicolumn{4}{c|}{ Група обстежених } \\
\cline { 2 - 5 } & $\begin{array}{c}\text { основна група } \\
(\mathrm{n}=137)\end{array}$ & $\begin{array}{c}\text { група порівняння } \\
(\mathrm{n}=38)\end{array}$ & $\begin{array}{c}\text { контрольна група } \\
(\mathrm{n}=32)\end{array}$ & $\begin{array}{c}\text { ступінь імунних } \\
\text { порушень }\end{array}$ \\
\hline Лейкоцити, 10\%л & $5,46 \pm 0,02^{*}$ & $5,58 \pm 0,01^{*}$ & $4,64 \pm 0,01$ & $\mathrm{I}$ \\
\hline Еозиносріли, \% & $1,49 \pm 0,3$ & $1,47 \pm 0,2$ & $1,3 \pm 0,2$ & $\mathrm{I}$ \\
\hline Нейтрофріли паличкоядерні, \% & $4,11 \pm 0,3$ & $4,08 \pm 0,3$ & $4,3 \pm 0,3$ & $\mathrm{I}$ \\
\hline Нейтрофріли сегментарні, \% & $57,9 \pm 0,5$ & $59,1 \pm 0,51$ & $68,2 \pm 0,48$ & $\mathrm{I}$ \\
\hline Моноцити, \% & $8,7 \pm 0,14^{*}$ & $8,8 \pm 0,15^{*}$ & $7,5 \pm 0,14$ & $\mathrm{II}$ \\
\hline Лейкоцитарний індекс інтоксикації & $1,42 \pm 0,18^{*}$ & $1,46 \pm 0,21^{*}$ & $1,95 \pm 0,15$ & $\mathrm{II}$ \\
\hline Індекс алергізації & $0,66 \pm 0,03$ & $0,65 \pm 0,04$ & $0,57 \pm 0,02$ & $\mathrm{II}$ \\
\hline Лімфоцити, \% & $29,7 \pm 1,9$ & $29,5 \pm 2,1$ & $23,9 \pm 2,2$ & $\mathrm{II}$ \\
\hline
\end{tabular}

Примітка тут і в таблицях 3, 4 і 5: * - різниця вірогідна порівняно з контрольною групою, p<0,05.

Виявлені імунні порушення (II ступінь) характеризуються різким зниженням відносної кількості моноцитів/макрофрагів, які розрізняють генетично чужорідні речовини та клітини, одночасно зростає інтоксикація організму пацієнток, які в нашому дослідженні - відсутні. У обстежених жінок зростає інтоксикація (за лейкоцитарним індексом інтокси- кації) та відносна кількість сегментоядерних нейтрофрілів на фооні зниження відносної кількості моноцитів і загальної кількості лейкоцитів.

Під час вивчення показників Т- і В-клітинної ланки імунітету виявлено зміни кількісного складу різних субпопуляцій лімфоцитів порівняно 3 контрольною групою (табл. 3).

Таблиця 3. Показники клітинної ланки імунітету в обстежених жінок

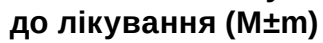

\begin{tabular}{|l|c|c|c|c|c|c|}
\hline \multirow{2}{*}{$\begin{array}{c}\text { Група } \\
\text { обстежених }\end{array}$} & \multicolumn{5}{|c|}{ Показиик } \\
\cline { 2 - 7 } & $\mathrm{CD} 3+, \%$ & $\mathrm{CD} 4+, \%$ & $\mathrm{CD} 8+, \%$ & $\mathrm{CD} 4+/ \mathrm{CD} 8+$ & $\mathrm{CD} 16+, \%$ & CD22+, \% \\
\hline $\begin{array}{l}\text { Основна група } \\
(\mathrm{n}=137)\end{array}$ & $75,3 \pm 2,3^{*}$ & $52,7 \pm 2,1^{*}$ & $32,4 \pm 2,5^{*}$ & $1,51 \pm 0,4$ & $14,8 \pm 2,3^{*}$ & $1^{*}, 9^{*} 2,2^{*}$ \\
\hline $\begin{array}{l}\text { Група порівняння } \\
(\mathrm{n}=38)\end{array}$ & $74,1 \pm 2,5^{*}$ & $53,1 \pm 2,2^{*}$ & $32,2 \pm 2,5^{*}$ & $1,54 \pm 0,5$ & $15,4 \pm 2,4^{*}$ & $13,2 \pm 2,1^{*}$ \\
\hline $\begin{array}{l}\text { Контрольна група } \\
(\mathrm{n}=32)\end{array}$ & $54,2 \pm 2,4$ & $359 \pm 2,6$ & $21,1 \pm 2,4$ & $1,78 \pm 0,5$ & $11,9 \pm 2,2$ & $19,1 \pm 2,1$ \\
\hline
\end{tabular}

На порушення співвідношення субпопуляцій Т-лімфоцитів вказує імунорегуляторний індекс (CD4+/CD8+), який у жінок основної групи був знижений на 15,2 \% $(p<0,05)$. На фроні зниження показників Т-ланки імунітету в жінок основної групи на 32,5 \% підвищувався процентний вміст CD22+-лімфроцитів, хоча вірогідної різниці між показниками основної групи й групи порівняння не виявлено ( $>>0,05)$. Зниження імунорегуляторного індексу (II ступінь імунних порушень) свідчить про розпізнавання та реципрокну функцію у межах аутономної імунокорекції.
Для аналізу функціонального стану гуморальної ланки імунної системи ми визначили три основні класи імуноглобулінів IgA, IgM, IgG у сироватці крові (табл. 4).

Отримані дані свідчать про те, що середня концентрація IgM в основній групі майже в 1,42 раза була нижчою, ніж у контрольній групі; рівень IgA був на 19,1 \%, a IgG - на 15,6 \% вищим. Рівень циркулюючих імунних комплексів (ЦІК) у жінок основної групи майже в 1,2 раза та в жінок контрольної групи у 2,4 раза перевищував показники норми $(p<0,05)$. 
Таблиця 4. Показники гуморальної ланки імунітету

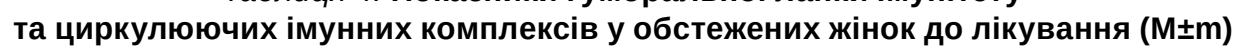

\begin{tabular}{|l|c|c|c|c|}
\hline \multicolumn{1}{|c|}{$\begin{array}{c}\text { Група } \\
\text { обстежених }\end{array}$} & \multicolumn{3}{|c|}{ Показник } \\
\cline { 2 - 5 } & $\operatorname{IgA}$, г/л & $\operatorname{IgM}$, г/л & $\operatorname{lgG}$, г/л & ЦІК, ум. од. \\
\hline $\begin{array}{l}\text { Основна група } \\
(\mathrm{n}=137)\end{array}$ & $1,33 \pm 0,2^{\star}$ & $0,9 \pm 0,21^{*}$ & $10,6 \pm 1,2^{\star}$ & $25,2 \pm 4,8^{*}$ \\
\hline $\begin{array}{l}\text { Група порівняння } \\
(\mathrm{n}=38)\end{array}$ & $1,32 \pm 0,1^{*}$ & $1,06 \pm 0,20^{*}$ & $10,5 \pm 1,2^{\star}$ & $25,8 \pm 5,1^{*}$ \\
\hline $\begin{array}{l}\text { Контрольна група } \\
(\mathrm{n}=32)\end{array}$ & $1,09 \pm 0,1$ & $1,28 \pm 0,18$ & $9,6 \pm 1,3$ & $59,6 \pm 5,0$ \\
\hline
\end{tabular}

У результаті проведеного кореляційного аналізу між досліджуваними показниками гуморальної ланки імунної системи були виявлені такі закономірності: негативний кореляційний взаємозв'язок між вмістом IgM i IgG ( $r=-0,49, p<0,05)$, IgM i IgA

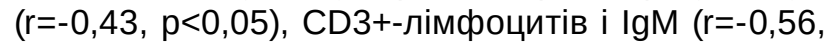

p<0,05). Кількість CD3+-лімфоцитів також негативно корелювала з рівнем ЦІК $(r=-0,37, p<0,05)$.

У роботі проаналізовано основні показники фрагоцитозу, комплементу та титр природних нормальних антитіл у сироватці крові обстежених жінок (табл. 5).

Таблиця 5. Показники факторів неспецифічної ефекторної системи протиінфекційного захисту в

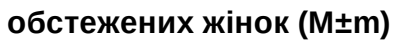

\begin{tabular}{|c|c|c|c|c|}
\hline \multirow{2}{*}{$\begin{array}{c}\text { Група } \\
\text { обстежених }\end{array}$} & \multicolumn{4}{|c|}{ Показник } \\
\cline { 2 - 5 } & О-лімсроцити, \% & $\begin{array}{c}\text { резерв бактерицидної } \\
\text { активності, \% }\end{array}$ & $\begin{array}{c}\text { титр комплементу, } \\
\%\end{array}$ & ФІ \\
\hline Основна група $(\mathrm{n}=137)$ & $37,1 \pm 0,94^{*}$ & $21,2 \pm 1,5^{*}$ & $0,04 \pm 0,005^{*}$ & $5,1 \pm 0,28^{*}$ \\
\hline Група порівняння $(\mathrm{n}=38)$ & $37,6 \pm 0,85^{*}$ & $20,9 \pm 1,4^{*}$ & $0,02 \pm 0,005^{*}$ & $4,81 \pm 0,25^{\star}$ \\
\hline Контрольна група $(\mathrm{n}=32)$ & $49,84 \pm 0,85$ & $14,8 \pm 1,2$ & $0,13 \pm 0,005$ & $3,9 \pm 0,18$ \\
\hline
\end{tabular}

У результаті проведеного дослідження отримано зниження неспецифічної резистентності організму, яке проявляється порушенням здатності до захоплення поліморфноядерних лейкоцитів, за рахунок підвищення титру комплементу в 3 рази. Крім порушень фрагоцитозу на початкових стадіях, зафріксовано зниження потенційної бактерицидної активності та її резерву. 3 цього можна зробити висновок, що в обстежених жінок не існує показань до призначення етіотропної імунотерапії, але, враховуючи збільшення в 1,2 раза рівня ЦІК відносно показників норми 3 метою попередження первинних проявів дисорункції імунної системи та для підвищення ефективності запропонованого лікувально-профілактичного комплексу, використовуємо імунокорегуючу терапію.

\section{Висновки}

Доведено, що основними фракторами порушення репродуктивної функції у жінок із безпліддям при лейоміомі матки $€$ зменшення концентрації естрадіолу при незміненому рівні прогестерону ( $>0,05)$ в обстежених жінок основної групи на 2-3 дні менструального циклу та достовірне зниження прогестерону в жінок основної групи й групи порівняння на 21-й день циклу. У жінок основної групи та групи порівняння спостерігали статистично вагоме зменшення рівня естрадіолу в крові $((60,27 \pm 0,004)$ та $(66,69 \pm 0,003)$ нмоль/л). Отримано зниження співвідношення ЛГ до ФСГ у межах 1,18-1,2 при необхідному фрізіологічному балансі $(1,5-2,0)$, що свідчить про відхилення в гормонопродукувальній функції яєчників.
Також виявлено, що у порушенні репродуктивної функції задіяний імунологічний гомеостаз, який характеризується змінами специфічного та неспециорічного імунітету в жінок із безпліддям на фроні лейоміоми матки в програмах допоміжних репродуктивних технологій, що мають субкомпенсований характер за рахунок зниження потенційної здатності бактерицидної активності фрагоцитарних клітин, зниження коефіцієнта активності фрагоцитарних клітин на 52,4 \%, збільшення імунологічного коефріцієнта і відносної кількості О-лімфоцитів; зменшення на 48,2 \% відносної кількості Т-лімфоцитів, лейко-Т-клітинного індексу та імунорегуляторного індексу на фроні збільшення на 50,3 \% відносної кількості CD8+ цитолітичних лімфоцитів. Враховуючи отримані дані, необхідною умовою реалізації репродуктивної функції є корекція виявлених змін шляхом оптимізації лікувально-профрілактичного комплексу.

Перспективи подальших досліджень. Заплановано оцінити запропоновану прегравідарну терапію та застосовані програми допоміжних репродуктивних технологій у жінок із безпліддям на фоні лейоміоми матки.

Зв'язок публікації з плановими науково-дослідними роботами. Робота $є$ фррагментом НДР кафедр ТНМУ «Клініко-патогенетичні аспекти діагностики, лікування та профрілактики ускладнень у жінок з порушенням репродуктивної функції та при супутній соматичній екстрагенітальній патології», № державної реєстрації 0116u003909. 


\section{Список літератури}

1. Онищук О. Д. Оптимізація підготовки жінок з безпліддям до запліднення in vitro після невдалих попередніх спроб / О. Д. Онищук // Здоровье женщины. - 2015. - № 10 (106). - С. 112-117.

2. Сучасні погляди репродуктолога на етіопатогенез і лікування лейоміоми матки / Н. В. Авраменко, Д. Є. Барковський, О. В. Кабаченко, Д. В. Лецин // Запорізький медичний журнал. - 2017. - Т. 19, № 3 (102). - С. $381-386$.

3. Alterations in uterine hemodynamics caused by uterine broids and their impact on in vitro fertilization outcomes $/$ J.-W. Moon, C.-H. Kim, J.-B. Kim [et al.] // Clin. Exp. Reprod. Med. - 2015. - Vol. 42 (4). - P. 163-168.

4. Deligdish L. Endometrial changes associated with myomata of uterus / L. Deligdish, M. Loewenthal // J. CHn Pathol. 2014. - Vol. 23 (8). - P. 676-680.

5. Identifying patients who can improve fertility with myomectomy / T. Samejima, K. Koga, H. Naake [et al.] // Eur. J. Obstet. Gynecol. Reprod. Biol. - 2015. - Vol. 185. - P. 28-32.

6. Optimization of metods diagnostics and treatment of submucosal leiomyomas in woman of reproductive age / O. Doroha, I. Iarotska, A. Vitiuk, H. Strelko // Georgian Medical News. - 2019. - Vol. 12 (297). - P. 35-41.

7. Potential of minimally invasive procedures in the treatment of uterine broids: a focus on magnetic resonance-guidet focused ultrasound therapy / K. Fischer, N. J. McDannold, C. M. Tempany // Int. J. Womens Health. - 2015. - Vol. 7. P. 901-912.

8. Zepiridis L. I. Infertility and uterine fibroids / L. I. Zepiridis, G. F. Grimbizis, B. C. Tarlatzis // Best Pract. Res. Clin. Obstet. Gynaecol. -2016. - Vol. 34. - P. 66-73.

\section{References}

1. Onyshchuk, O.D. (2015). Optymizatsiia pidhotovky zhinok z bezpliddiam do zaplidnennia in vitro pislia nevdalykh poperednikh sprob [Optimization of training of women with infertility to in vitro fertilization after unsuccessful previous attempts]. Zdorovye zhenshchyny - Women's Health, 10 (106), 112-117 [in Ukrainian].

2. Avramenko, N.V., Barkovskyi. D.Ye., Kabachenko, O.V., \& Letsyn, D.V. (2017). Suchasni pohliady reproduktoloha na etiopatohenez i likuvannia leiomiomy matky [Modern views of the reproductive specialist on the etiopathogenesis and treatment of uterine leiomyoma]. Zaporizkyi medychnyi zhurnal - Zaporozhye Medical Journal, 19, 3 (102), $381-386$ [in Ukrainian].

3. Moon, J.-W., Kim, C.-H., Kim, J.-B., Chae, H.-D., \& Kang, B.-M. (2015). Alterations in uterine hemodynamics caused by uterine broids and their impact on in vitro fertilization outcomes. Clin. Exp. Reprod. Med., 42 (4), 163-168. DOI: 10.5653/ cerm.2015.42.4.163.

4. Deligdish, L., \& Loewenthal, M. (2014). Endometrial changes associated with myomata of uterus. J. CHn Pathol., 23, 676-680. DOI: 10.1136/jcp.23.8.676.

5. Samejima, T., Koga, K., Nakae, H., Wada-Hiraike, O., Fujimoto, A., Fujii, T., \& Osuga, Y. (2015). Identifying patients who can improve fertility with myomectomy. Eur. J. Obstet. Gynecol. Reprod. Biol., 185, 28-32. DOI: 10.1016/j.ejogrb.2014.11.033. 6. Doroha, O., Iarotska, I., Vitiuk, A., \& Strelko, H. (2019). Optimization of metods diagnostics and treatment of submucosal leiomyomas in woman of reproductive age. Georgian medical news, 12 (297), 35-41.

7. Fischer K., McDannold, N.J., \& Tempany, C.M. (2015). Potential of minimally invasive procedures in the treatment of uterine broids: a focus on magnetic resonance- guidet focused ultrasound therapy. Int. J. Womens Health., 7, $901-912$. DOI: 10.2147/IJWH.S55564.

8. Zepiridis, L.I., Grimbizis, G.F., \& Tarlatzis, B.C. (2016). Infertility and uterine fibroids. Best Pract. Res. Clin. Obstet. Gynaecol., 34, 66-73. DOI: 10.1016/j.bpobgyn.2015.12.001.

\section{ANALYSIS OF FACTORS OF REPRODUCTIVE FUNCTION DISORDERS IN WOMEN WITH INFERTILITY AND UTERINE LEIOMYOMA IN ASSISTED REPRODUCTIVE TECHNOLOGY PROGRAMS}

Yu. B. Drozdovska

I. Horbachevsky Ternopil National Medical University, Ternopil, Ukraine

Purpose: to study the factors of reproductive dysfunction in infertile women with uterine leiomyoma by analyzing hormonal and immunological homeostasis and further optimization of the treatment and prevention complex.

Materials and Methods. A randomized prospective clinical study was conducted among 175 (29.0\%) women of reproductive age who were diagnosed with uterine leiomyoma (UL) and a control group (CG) of 32 somatically healthy women with normal menstrual and reproductive functions, who were divided into the following groups: Main Group (MG) A - 137 women with UL receiving the proposed treatment; Comparison Group (CG) B 38 women with UL receiving conventional treatment.

Results. An analysis of the reproductive hormonal panel in the examined women of the main group on day 2-3 of the menstrual cycle revealed a decrease in estradiol concentration with unchanged progesterone levels $(p>0.05)$ and a significant decrease in progesterone in women of the main group and the comparison group on day 21 of the cycle. In women of the main group and the comparison group, a statistically significant decrease in the level of estradiol in the blood was observed $(60.27 \pm 0.004)$ and $(66.69 \pm 0.003) \mathrm{nmol} / \mathrm{l}$. A decrease in the ratio of $\mathrm{LH}$ to FSH was detected in the range of 1.18-1.2, whereas the required physiological balance is 1.5-2.0, which indicates an impairment of the hormone-producing function of the ovaries. 
Conclussions. Changes in specific and nonspecific immunity observed in women with infertility and uterine leiomyoma in assisted reproductive technology programs are subcompensated by reducing the potential bactericidal activity of phagocytic cells, reducing the activity of phagocytic cells by $52.4 \%$, an increase in immunological coefficient and relative number of 0 -lymphocytes, a $48.2 \%$ decrease in the relative number of T-lymphocytes, leuko-T-cell index, and immunoregulatory index and a concurrent increase in the relative number of CD8 + cytolytic lymphocytes by $50.3 \%$.

KEY WORDS: infertility; uterine leiomyoma; steroid hormones; innate nonspecific immunity; specific immunity; assisted reproductive technologies.

Рукопис надійшов до редакції 26.08.2020 p.

\section{Відомості про автора:}

Дроздовська Юлія Богданівна - аспірант кафедри акушерства та гінекології № 1 Тернопільського

національного медичного університету імені І. Я. Горбачевського МОЗ України; тел.: +38(068) 583-67-39. 